\title{
Vytváření modelu terénu s využitím geodetických dat Českého úřadu geodetického a katastrálního v prostředí simulačních softwarů
}

\author{
Terrain Model Created in Software with Using of Czech Office for Surveying, \\ Mapping and Cadastre Data
}

Ivo Drahotský*

Univerzita Pardubice, Dopravni fakulta Jana Pernera

\begin{abstract}
Abstrakt:
Text př́íspěvku je zaměřen na vytváření modelu terénu $\mathrm{v}$ prostředi softwarových analytických nástrojů s využitím v České republice volně dostupných geodetických dat. Uživateli je předkládán metodický postup, jakým způsobem získat, zpracovat a implementovat informace ze zdrojů ČÚZK pro tvorbu modelu terénu. Příspěvek vznikl za podpory Ministerstva vnitra ČR, programu Bezpečnostního výzkumu - projektu VI20172020108.
\end{abstract}

Klíčová slova: 3D model, model terénu, geografická data, Virtual Crash, triangulace, analytický software, analýza nehod.

\section{1. ÚVOD}

V rámci technické analýzy dopravních nehod vyvstává mnohdy požadavek na vytvoření modelu terénu, který je možno přímo implementovat do některého $\mathrm{z}$ dostupných softwarových nástrojů (obvykle Virual Crash či PC-Crash).

Ne vždy jsou však $\mathrm{k}$ dispozici data pořízená vyšetřujícími orgány př́mo na místě dopravní nehody. Nemusí být rovněž dostupná data v rozsahu požadované rozlohy konkrétního místa, plochy, trasy komunikace, okolí místa nehody, a to např́klad za účelem vyjádření dohlednosti, respektive oblasti zakrytého výhledu, vrcholového oblouku, a podobně.

Samozřejmě existují možnosti přesného zaměření místa geodetickými totálními stanicemi, nicméně ne ve všech případech je požadavek na přesnost dat řádově v milimetrech opodstatněný, či by náročnost pořízení dat, at' již z hlediska pracnosti či nákladovosti, vysoce přesahovala činnosti spjaté s vlastní analýzou.

\begin{abstract}
:
The presented text is focused on the terrain model expression in the environment of software analytical tools using free geodetic data in the Czech Republic. The user is presented with a methodical procedure how to obtain, process and implement information from the ČÚZK sources to create a terrain model. The contribution was created with the support of the Ministry of the Interior of the Czech Republic, the Security Research Program VI20172020108.
\end{abstract}

Keywords: 3B model, terrain model, geographic data, Virtual Crash, triangulation, analytic software.

V České republice jsou však některá měření pořizována prostřednictvím státních či příspěvkových organizací, a jejich výstupy, respektive výstupní data jsou veřejně dostupná. Na serveru Státní správy zeměměřičství a katastru (www.cuzk.cz) je možné dohledat výstupy z laserového skenování zemského povrchu na území České republiky.

\section{POSTUP ZÍSKÁNÍ A UŽITÍ DAT}

Cílem příspěvku je poskytnout znalcům a kolegům z řad odborné veřejnosti metodický postup, s jehož pomocí lze získat, zpracovat a užít výškopisné informace z digitálního modelu reliéfu České republiky.

Následně je tedy popsána chronologie jednotlivých úkonů, prostřednictvím kterých lze vytvořit 3D model terénu a užít jej v simulačním softwaru. 


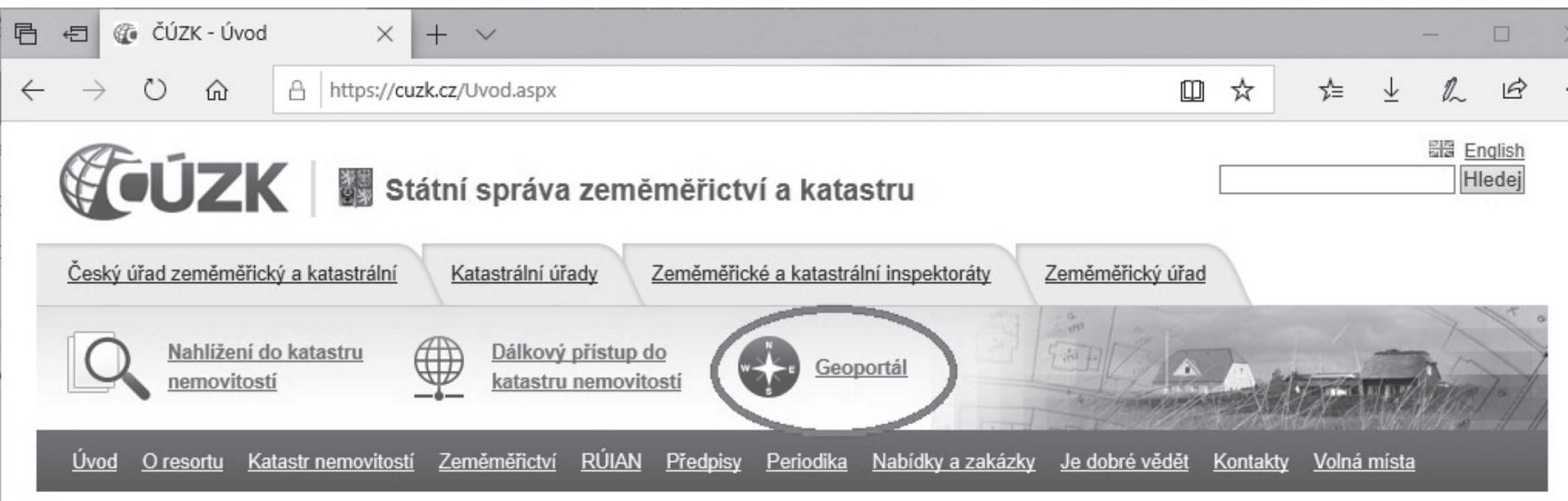

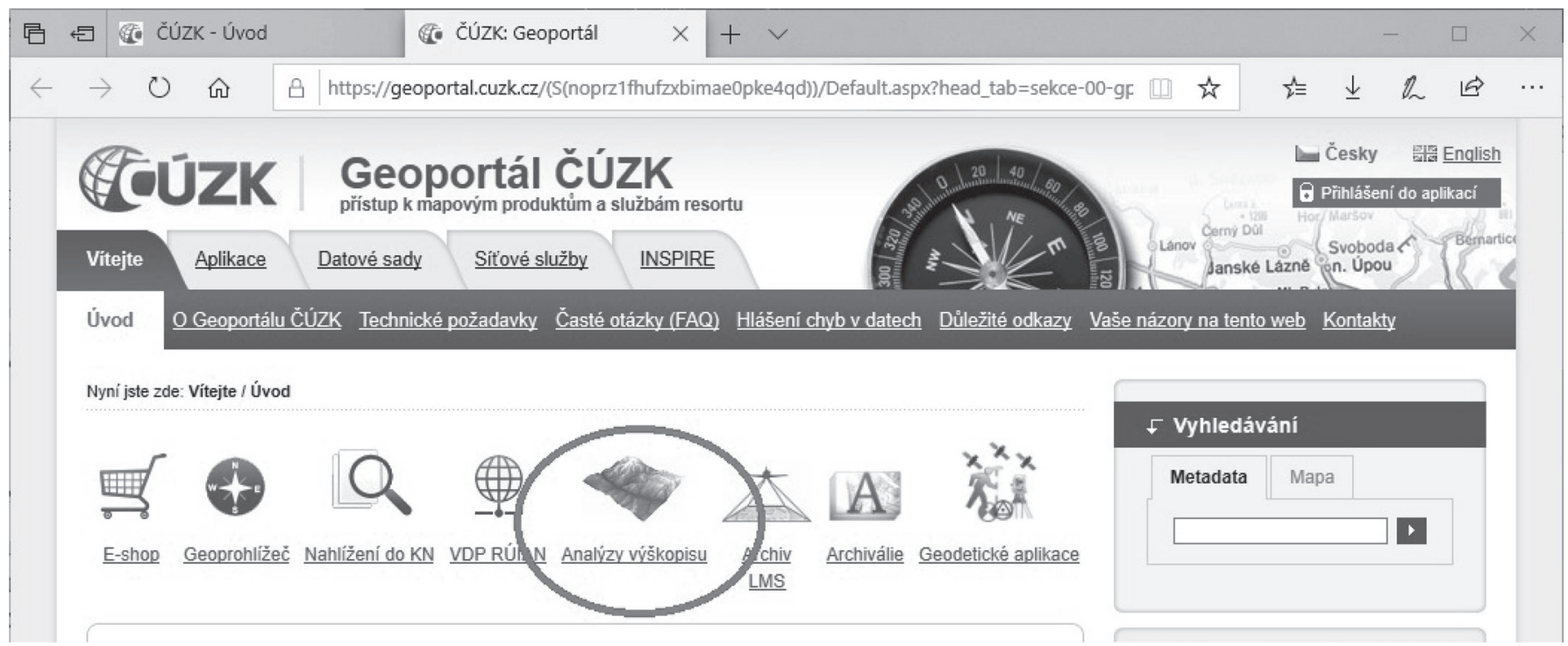

Obr. 1 www.cuzk.cz; geoportal.cuzk.cz.

Fig. 1 www.cuzk.cz; geoportal.cuzk.cz.

\subsection{Získání dat z geoportálu}

Data, které budou v rámci tvorby modelu terénu uživána, vychází z laserového skenování zemského povrchu, přičemž jsou tato data verifikována i validována $\mathrm{s}$ dalšími daty, včetně měření prostřednictvím totálních stanic $\mathrm{v}$ místech, kde tato měření byla prováděna. Laserové skenování probíhá opakovaně, kdy dochází $\mathrm{k}$ neustálému zpřesňování dat, eliminaci vegetace a podobně. Je zřejmé, že přesnost dat nedosahuje přesnosti měření totální stanicí,

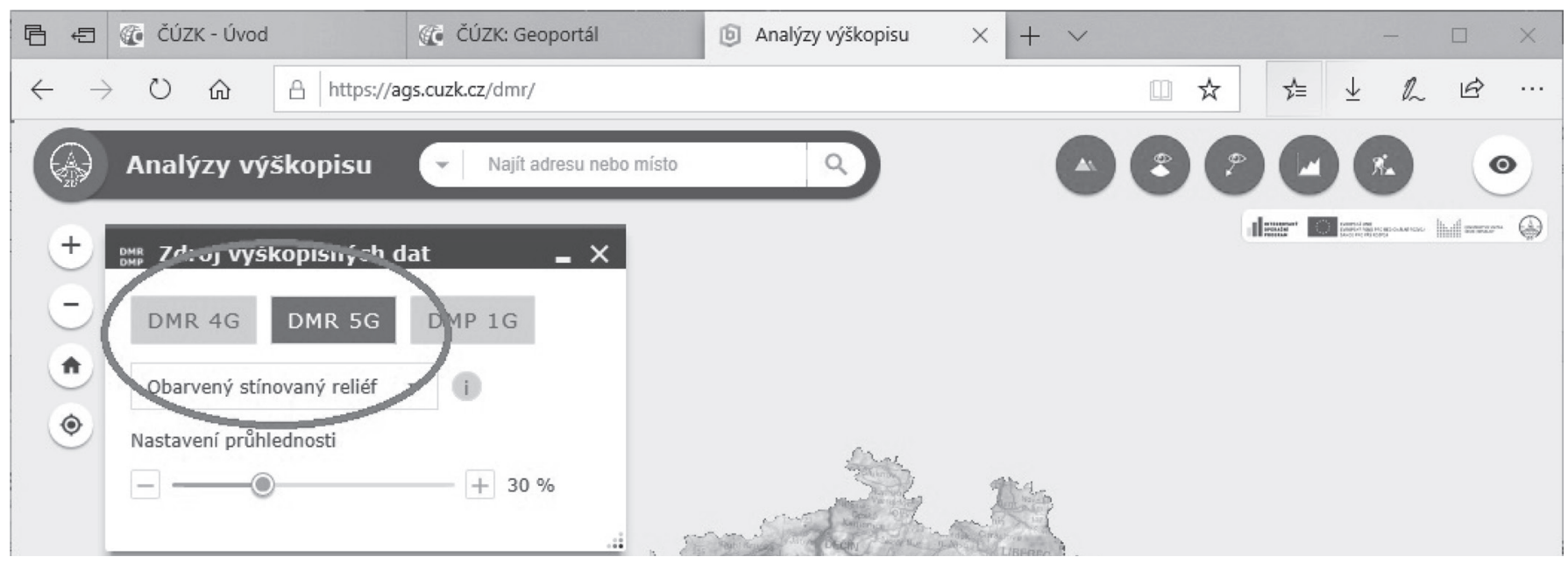

Obr. 2 Analýza výškopisu.

Fig. 2 Terrain analysis. 
s čímž je třeba uvažovat. Nicméně i tak jsou data využitelná pro vytvoření $3 \mathrm{D}$ modelu, $\mathrm{s}$ řádovou přesností $\mathrm{v}$ centimetrech. $\mathrm{V}$ případě nutnosti zpřesnění údajů lze data dále zpracovávat např́klad pro získání linie sklonových poměrů na určitém úseku, data vyhladit a podobně.

\subsubsection{Digitální model reliéfu - data}

První krok představuje vstup na portál ČÚZK (www.cuzk.cz) a potom na záložku „Geoportál“. Jedná se o př́stup k mapovým produktům a službám resortu. Př́ípadně prrímo na stránky https:// geoportal.cuzk.cz/ jak je uvedeno na obr. 1.

Následně je třeba spustit analýzu výškopisu.
Zde je možno provést nastavení digitálního modelu terénu, ze kterého budou čerpána data. Zdrojem výšpopisných dat je takzvaný digitální model reliéfu (DMR), který navazuje na původně užívaný digitální model povrchu (DMP). V současné době je dostupná 5 . generace DMR, kterou je vhodné nastavit - DMR 5G. Standardně je nastaven DMR 4G (obr. 2).

V mapě České republiky vyhledáme zájmové místo, u kterého chceme vytvořit model, abychom získali informace o terénu.

Poté zvolíme nabídku „Profil“, a následně „Kreslení lomené čáry nebo úsečky“" (obr. 3).

Prostřednictvím lomené čáry vyznačíme místo, které budeme dále zpracovávat. Každá část lomené čáry bude nést geodetická

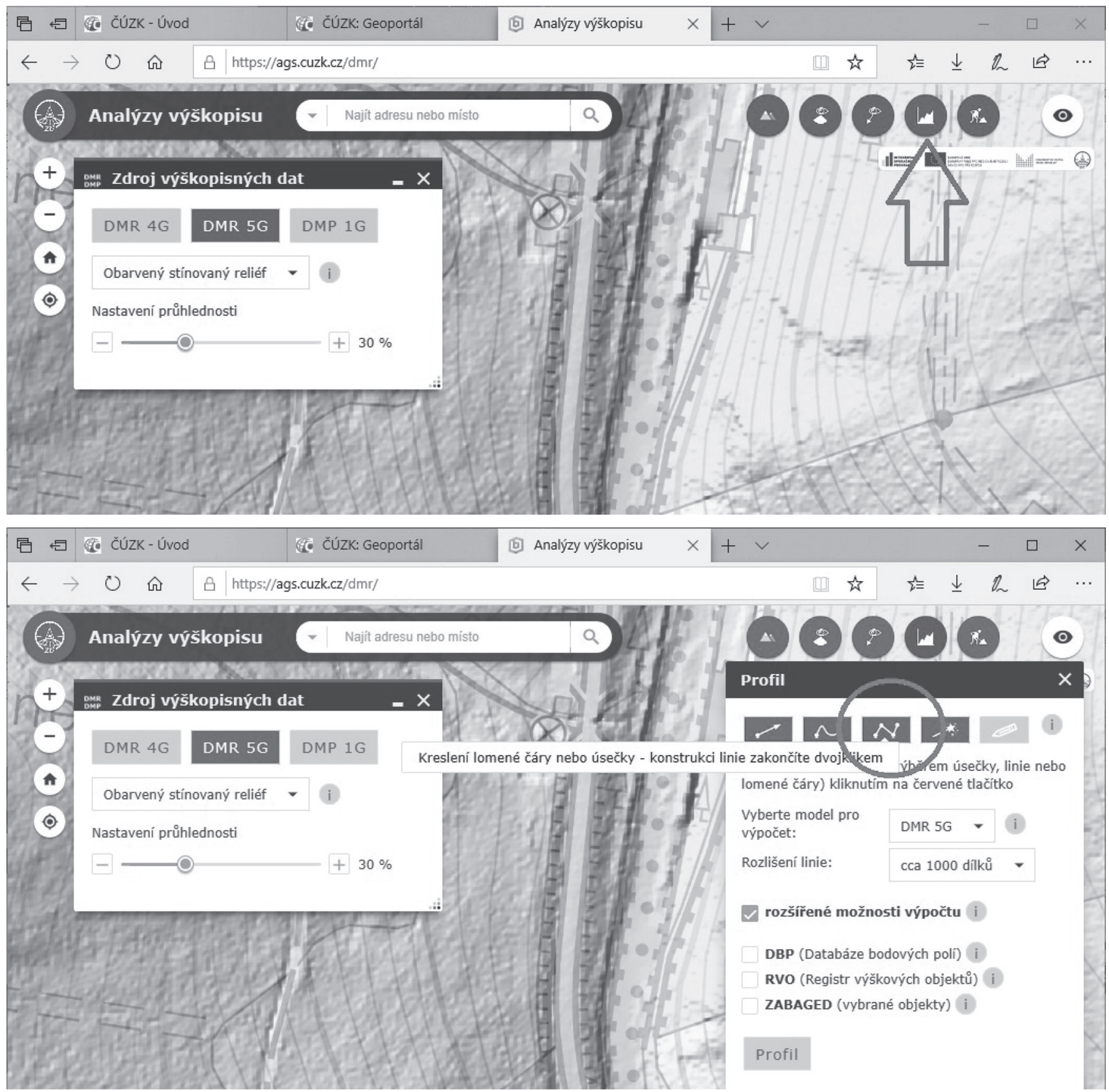

Obr. 3 Definice profilu.

Fig. 3 Profile definition. 

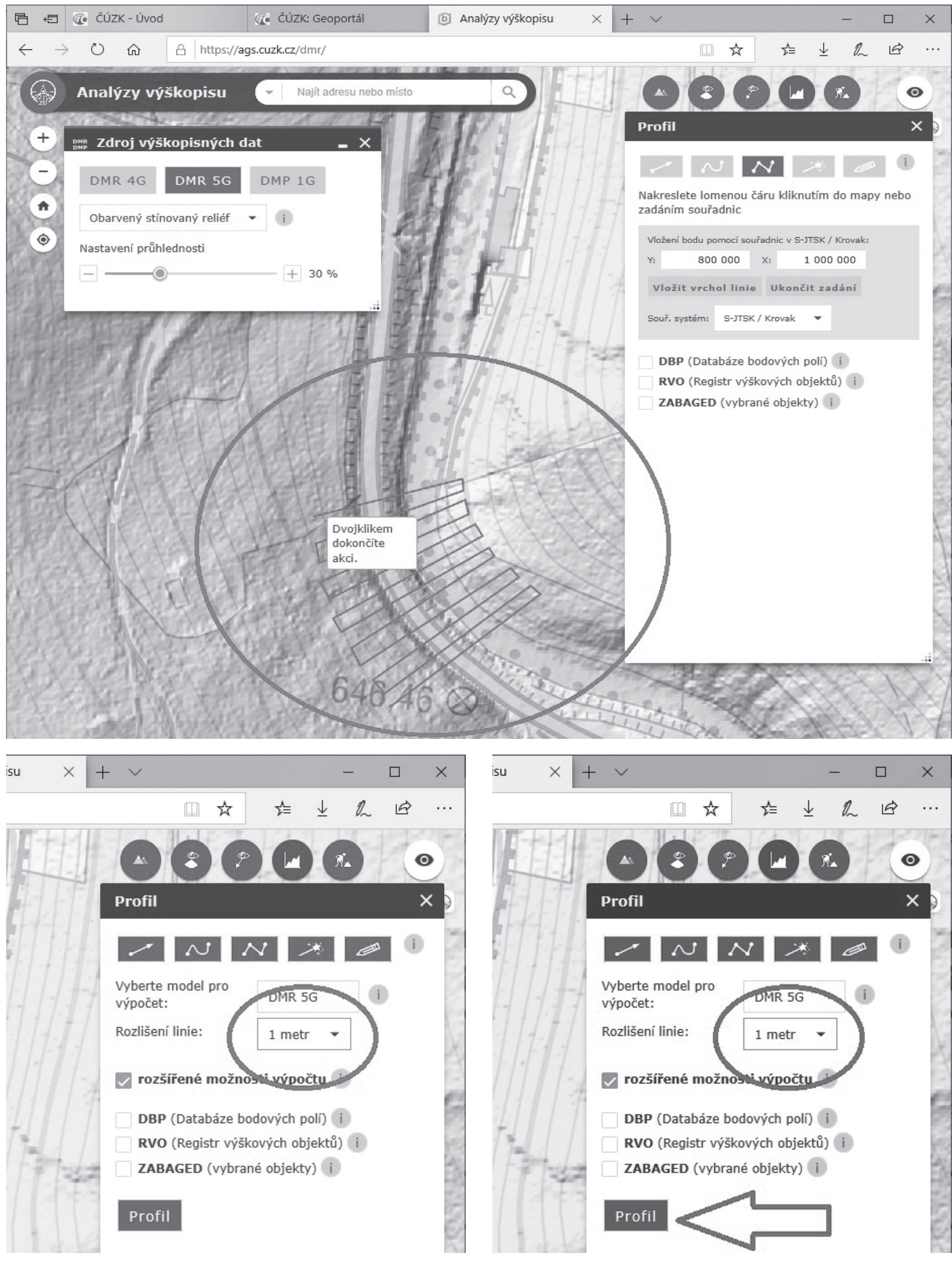

Obr. 4 Výběr bodů terénu.

Fig. 4 Terrain points definition. 


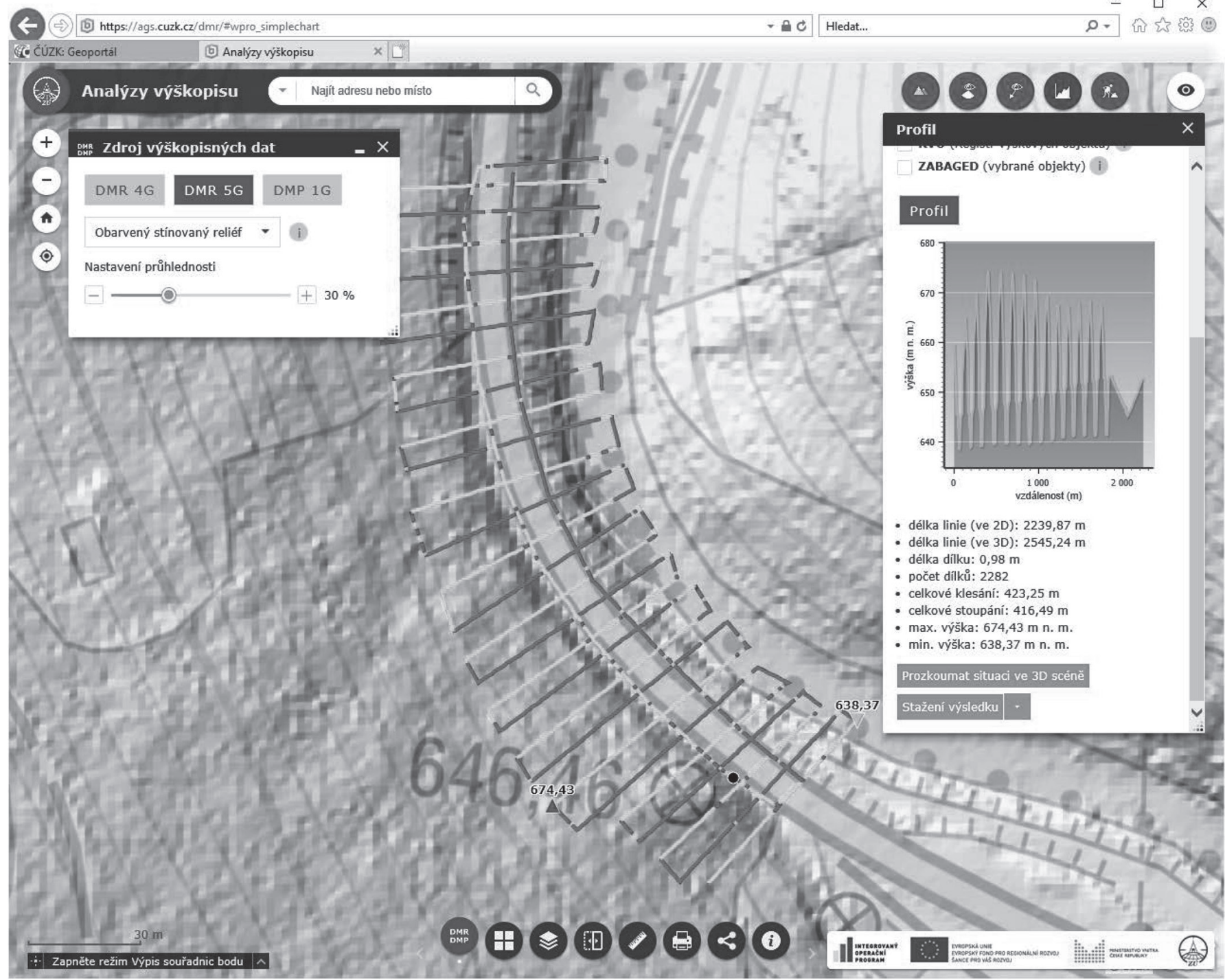

Obr. 5 Přiklad výsledku výběru bodů.

Fig. 5 Example of points definition.

data, proto je vhodné vytvořit například sít čar či šrafování.

V položce „Rozlišení linie“ je pro přesnější údaje vhodné vybrat hodnotu ,1 metr".

Následně stisknout tlačítko „Profil“ a aplikace vygeneruje požadovaná data (obr. 4,5$)$.

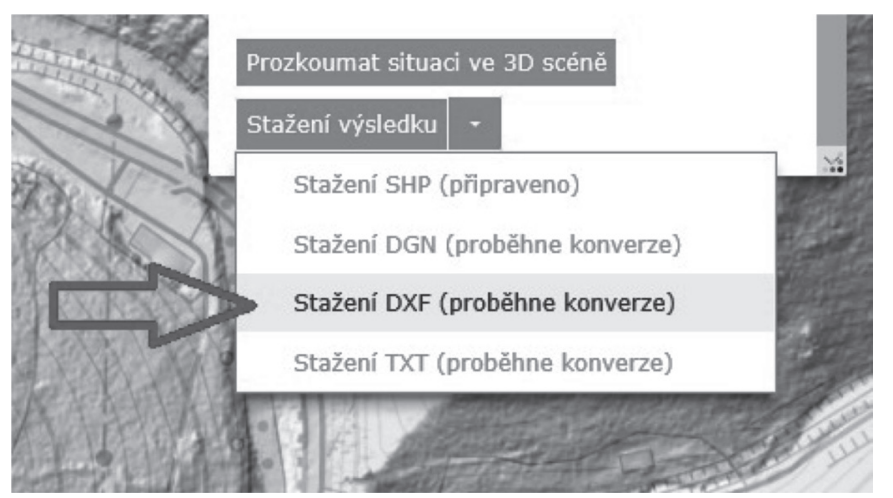

\subsection{Transformace a export vygenerovaných dat}

V okně „Profil““ je dole uvedena položka „Stažení výsledku“, která umožňuje stáhnout a uložit vygenerovaná data v několika formátech. Pro import do programu Virtual Crash (i programu PC-Crash) lze využít především formát DXF (př́ípadně TXT).

Dalším krokem tedy je stažení výsledku a uložení do PC (to provedeme aktivací nabídky u požadovaného souboru, který uložíme). Proběhne konverze a data jsou pak stahována ve formátu ZIP s tím, že jsou vždy komprimovány 4 soubory. Po stažení je třeba extrahovat soubor „vystupniLinieDXF_R2000.dxf“ obsahující informace o bodech terénu ve vyznačené oblasti (obr. 6).

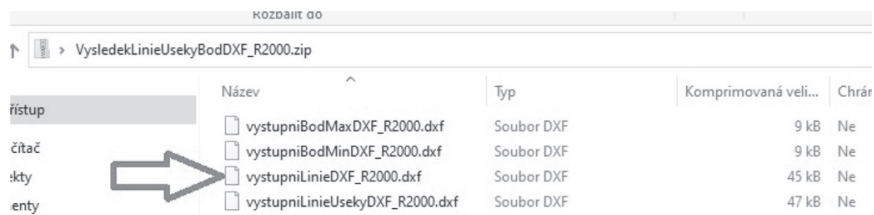



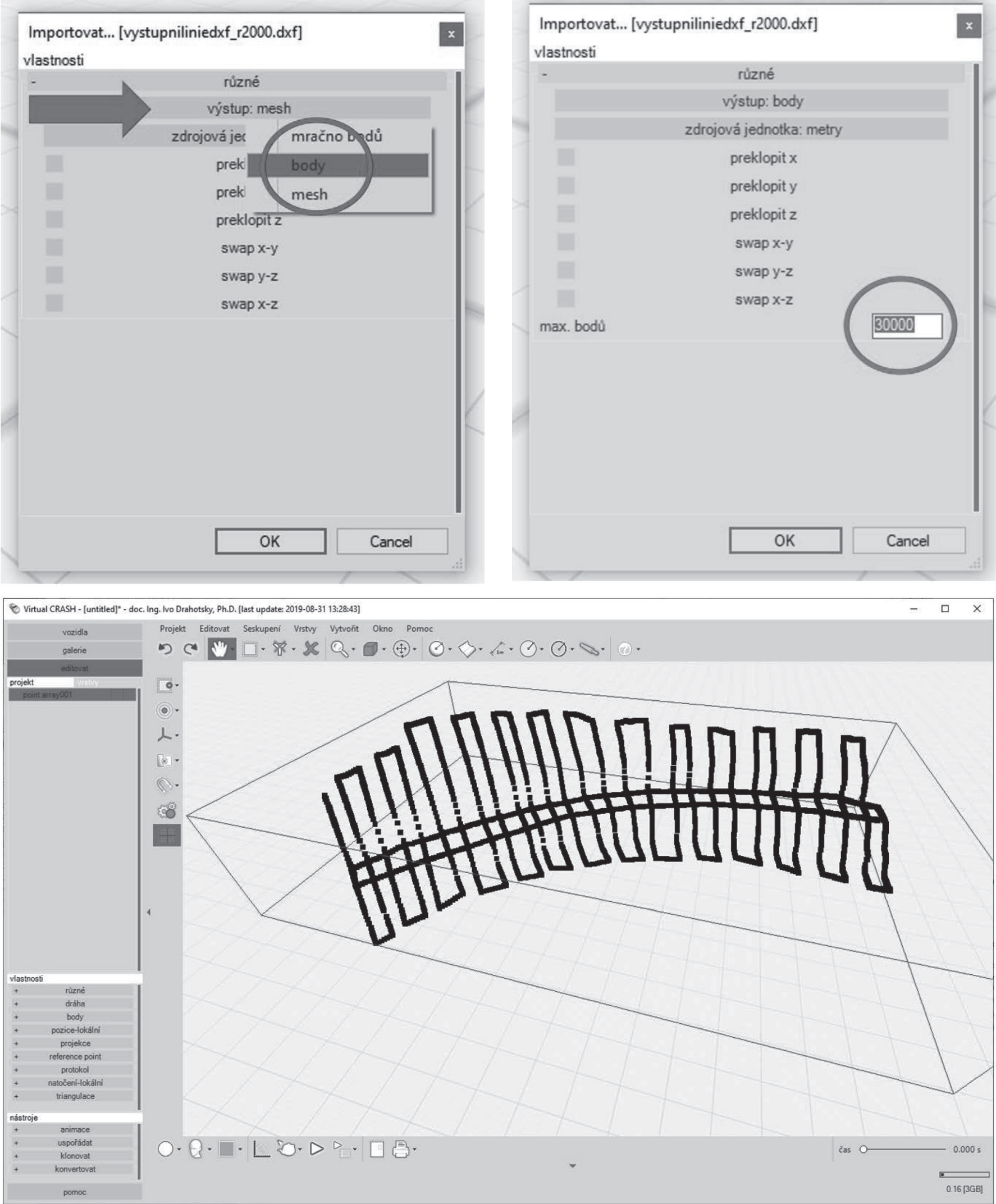

Obr. 7 Import dat.

Fig. 7 Data import.

2.3 Import vygenerovaných dat a tvorba 3D modelu terénu Následující postup je zpracován v softwaru Virual Crash, přičemž analogicky lze postupovat i v softwaru PC-Crash. Soubor
„vystupniLinieDXF_R2000.dxf“ přesuneme s využitím myši na aktivní plochu programu Virtual Crash. Případně můžeme soubor importovat prostřednictvím Projekt / Importovat. 
Po přetažení souboru se zobrazí nabídka importu. Zde je důležité v části „výstup“ změnit původní nastavení na „body“, a v části max. bodů změnit původní hodnotu „300“ na hodnotu vyšší (v závislosti na rozsahu požadovaných dat; $v$ prŕíkladu jsou přidány 2 nuly, tedy dva řády). Jestliže bude ponechána nižší hodnota, bude importován omezený počet bodů (obr. 7).
Takto získaná data sama o sobě 3D model terénu nepředstavují, je je třeba dále zpracovat. Označená data proto budeme triangulovat. Vybereme položku „triangulovat“, kterou aktivujeme, a odebereme nabídku „přidat rohy“, která je aktivní automaticky. Následující obrázek znázorňuje jednotlivé kroky postupu a výsledek (obr. 8).
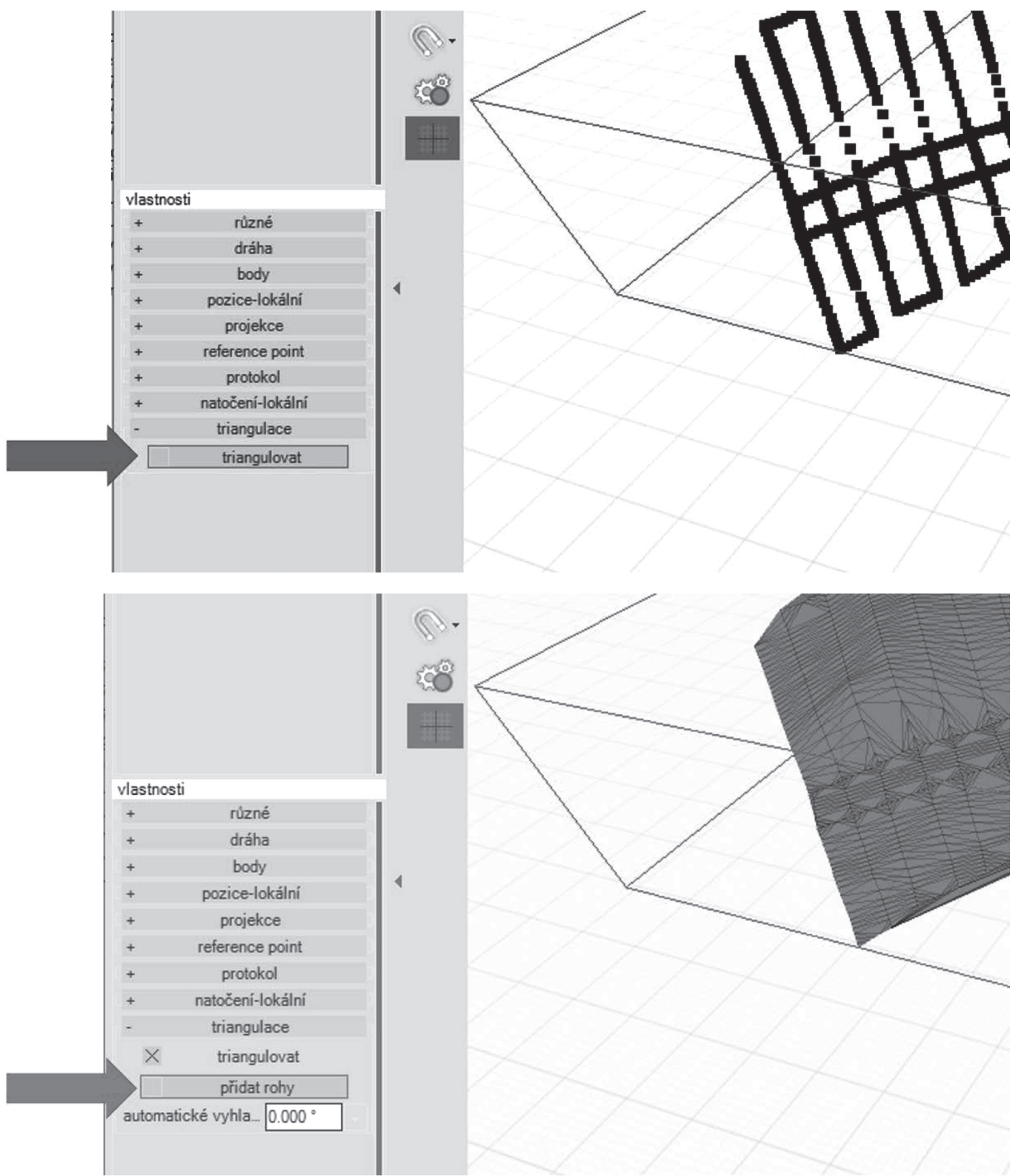

Obr. 8 Triangulace.

Fig. 8 Triangulation 


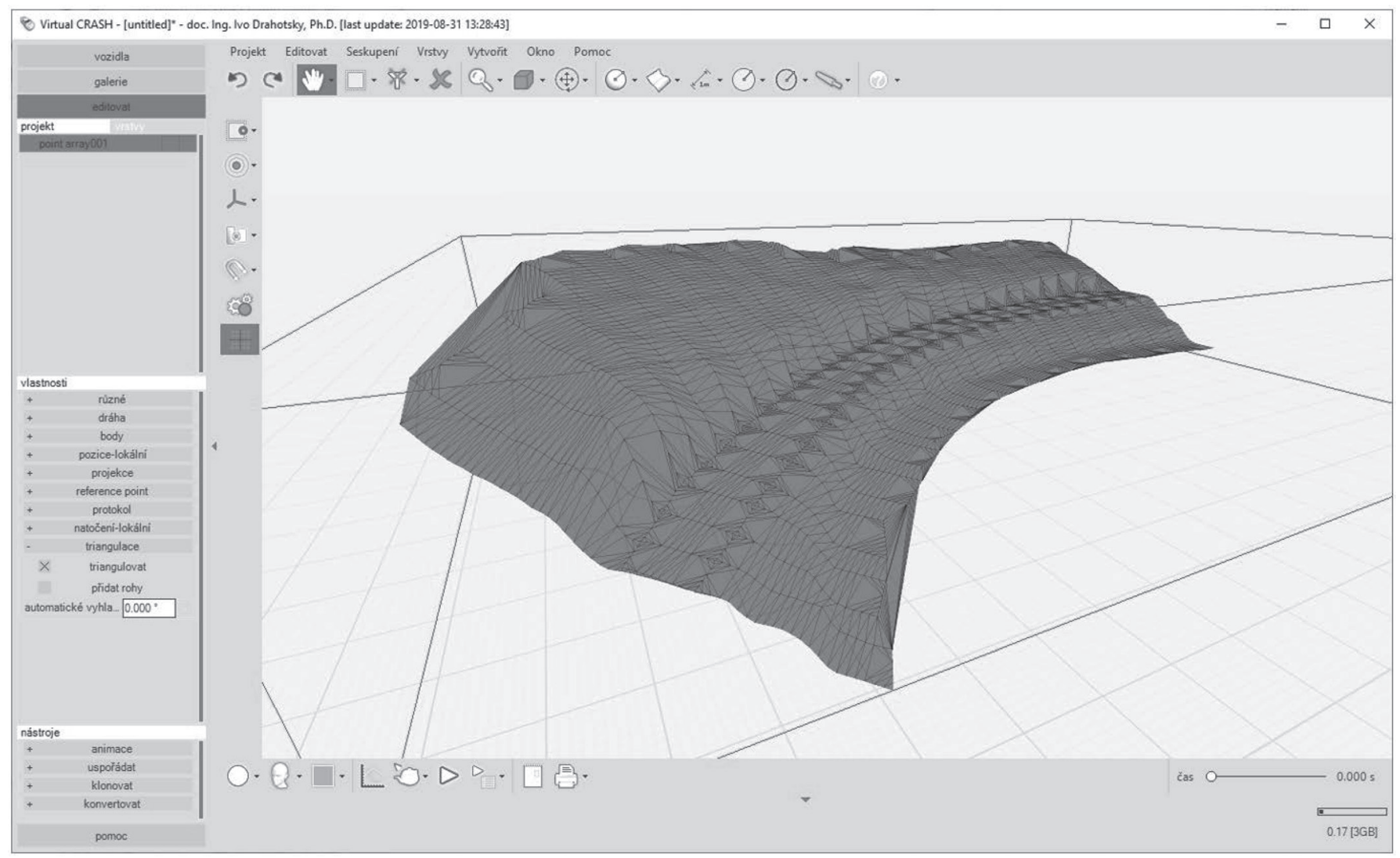

Obr. 8 Triangulace (pokračování).

Fig. 8 Triangulation (continuation).

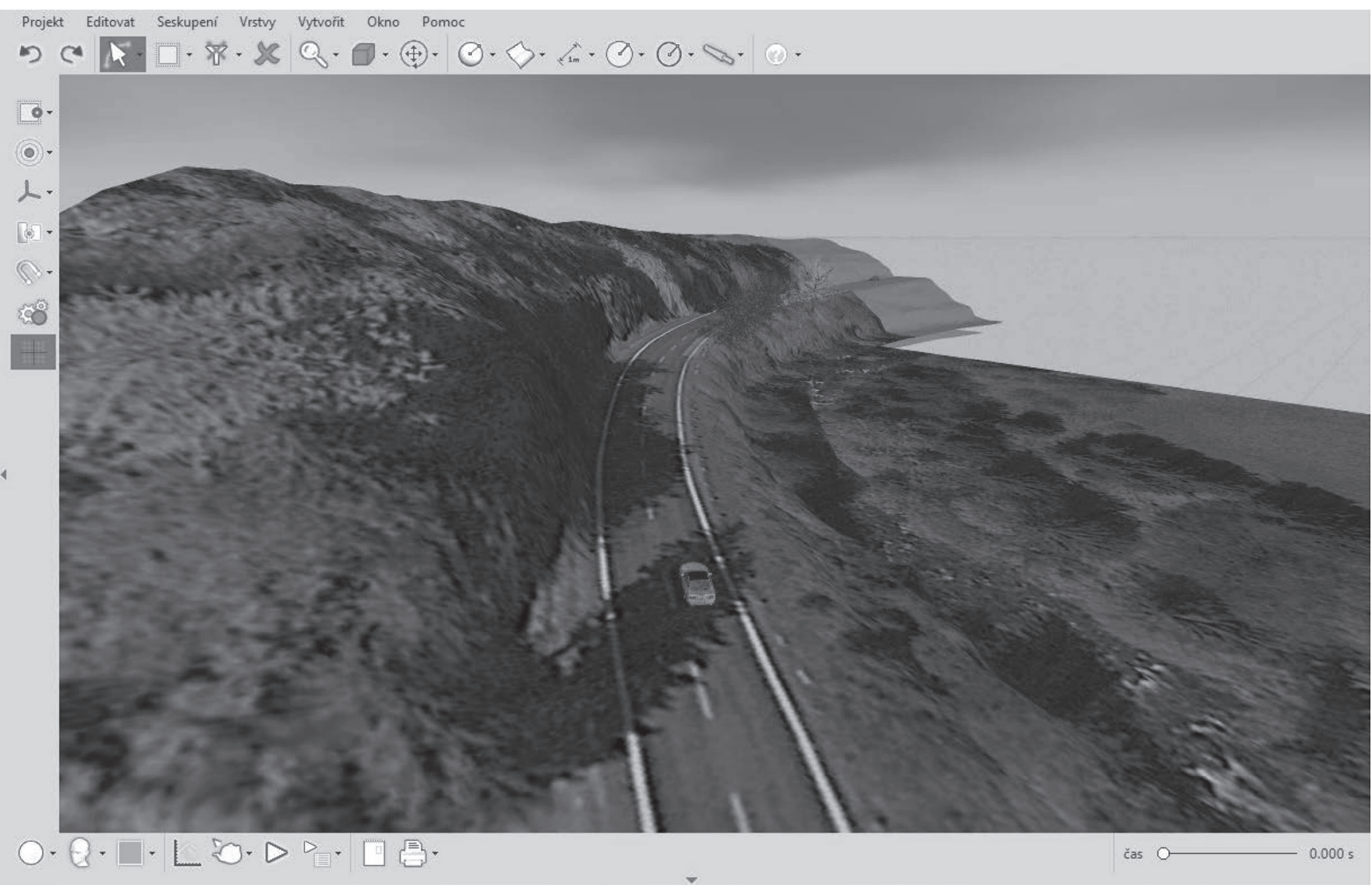

Obr. 9 Př́klad výstupu.

Fig. 9 Example of output. 
S takto získaným objektem lze následně standardně pracovat. Vytvořit terén - statické těleso z označených. Vložit mapový podklad a přijímat projekci, a podobně (obr. 9).

\subsection{Tvorba linie komunikace}

V některých případech může být vyžadováno získání linie komunikace v místě dopravní nehody, nebo v úseku, který dopravní nehodě předcházel. Jedná se např́klad o znázornění vrcholových oblouků, údolnicových oblouků, oblastí zakrytého výhledu a tak dále. Obdobně jako v předchozím př́padě lze i tato zadání vyřešit.

V aplikaci Geoportál je třeba označit nabídku „Přebírání geometrie“ a následně zaškrtnou položku „Komunikace“.
Poté je možno vybrat komunikaci (bude zvýrazněna) a označit v nabídce „Použít pro výpočet“. Následně stisknout „Profil““. I zde je možné definovat model pro výpočet DMR $5 \mathrm{G}$ a rozlišení linie.

Po vygenerování profilu je možno stáhnout a uložit informace (DXF) analogicky jako v préedcházejícím př́ípadě, importovat je do programu Virtual Crash a dále využívat.

Protože je uvedeným způsobem zobrazena vždy konkrétní komunikace $\mathrm{v}$ celé délce, je nutno odebrat přebytečné body a ponechat pouze ty body, které budou dále využity.

Jednotlivé kroky jsou opět uvedeny na obr. 10.

Protože se $\mathrm{v}$ daném případě jedná o body, které nelze použít jako dráhu, je nutno dílčími body (v půdorysu) proložit křivku
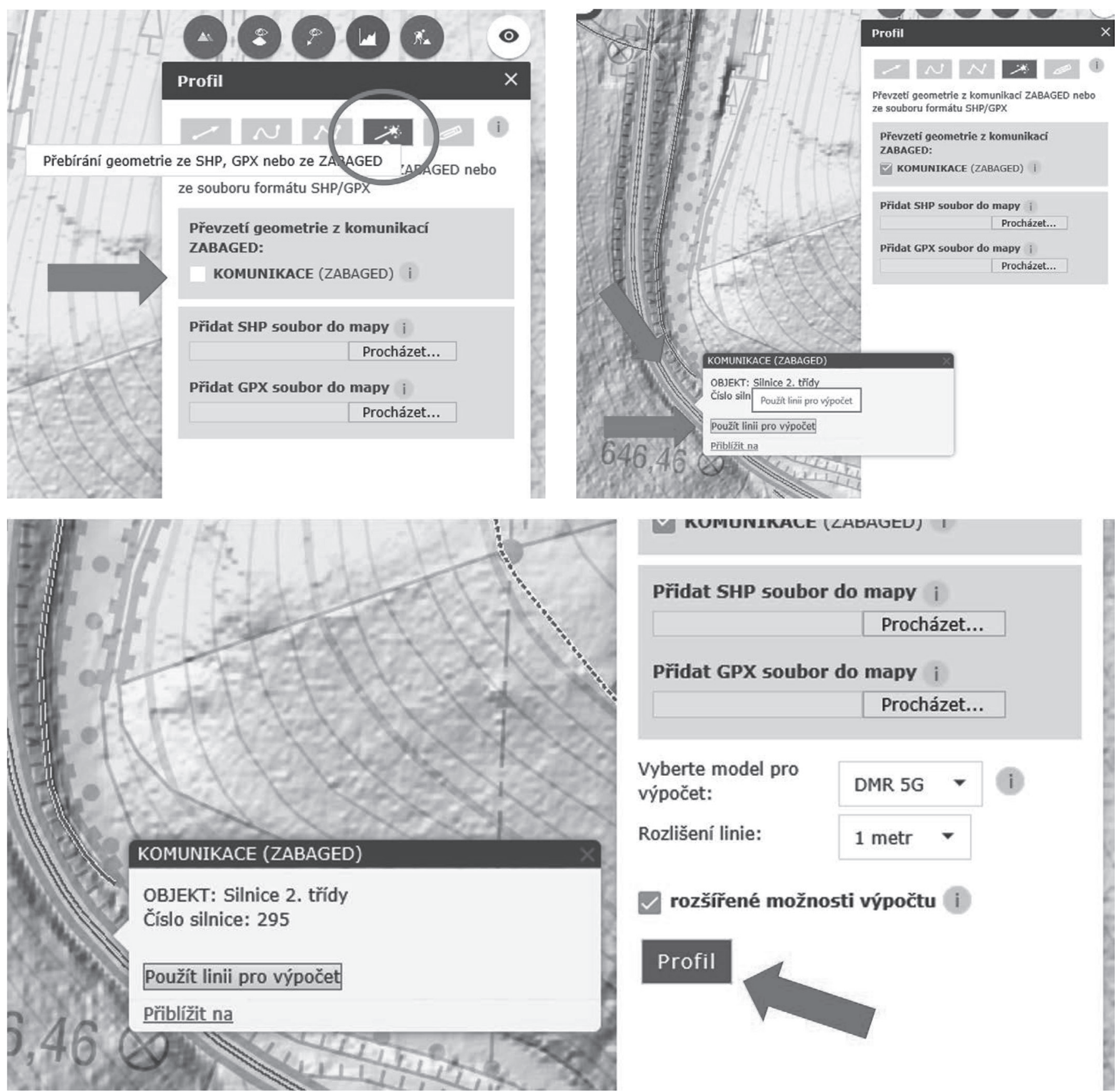

rozšiřené možnosti výpočtu i

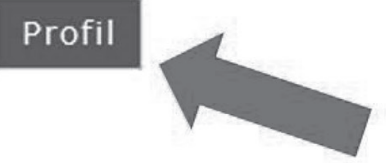

Obr. 10 Dílči kroky postupu tvorby linie komunikace.

Fig. 10 Steps of road model proces. 

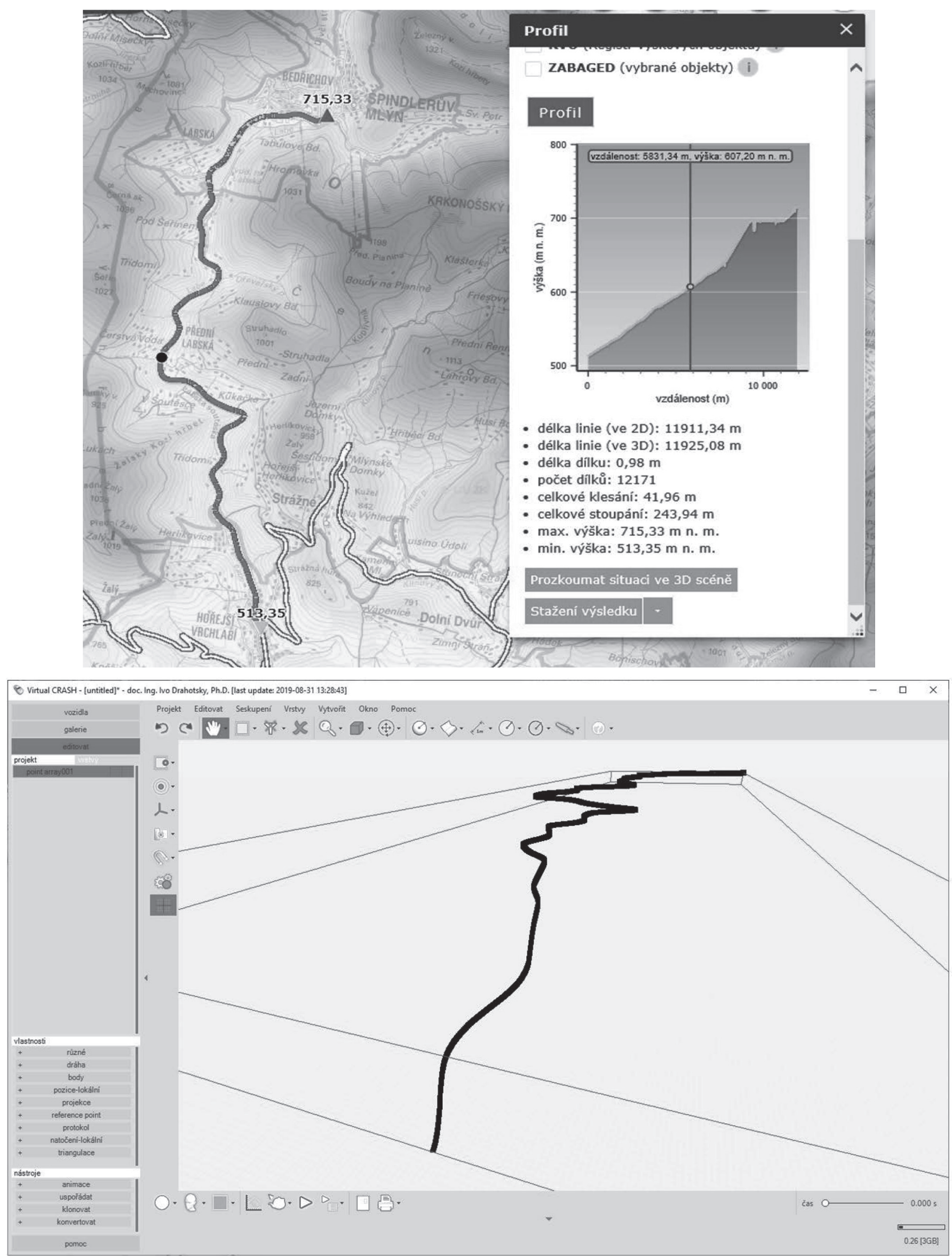

Obr. 10 Dílči kroky postupu tvorby linie komunikace (pokračování).

Fig. 10 Steps of road model proces (continuation). 


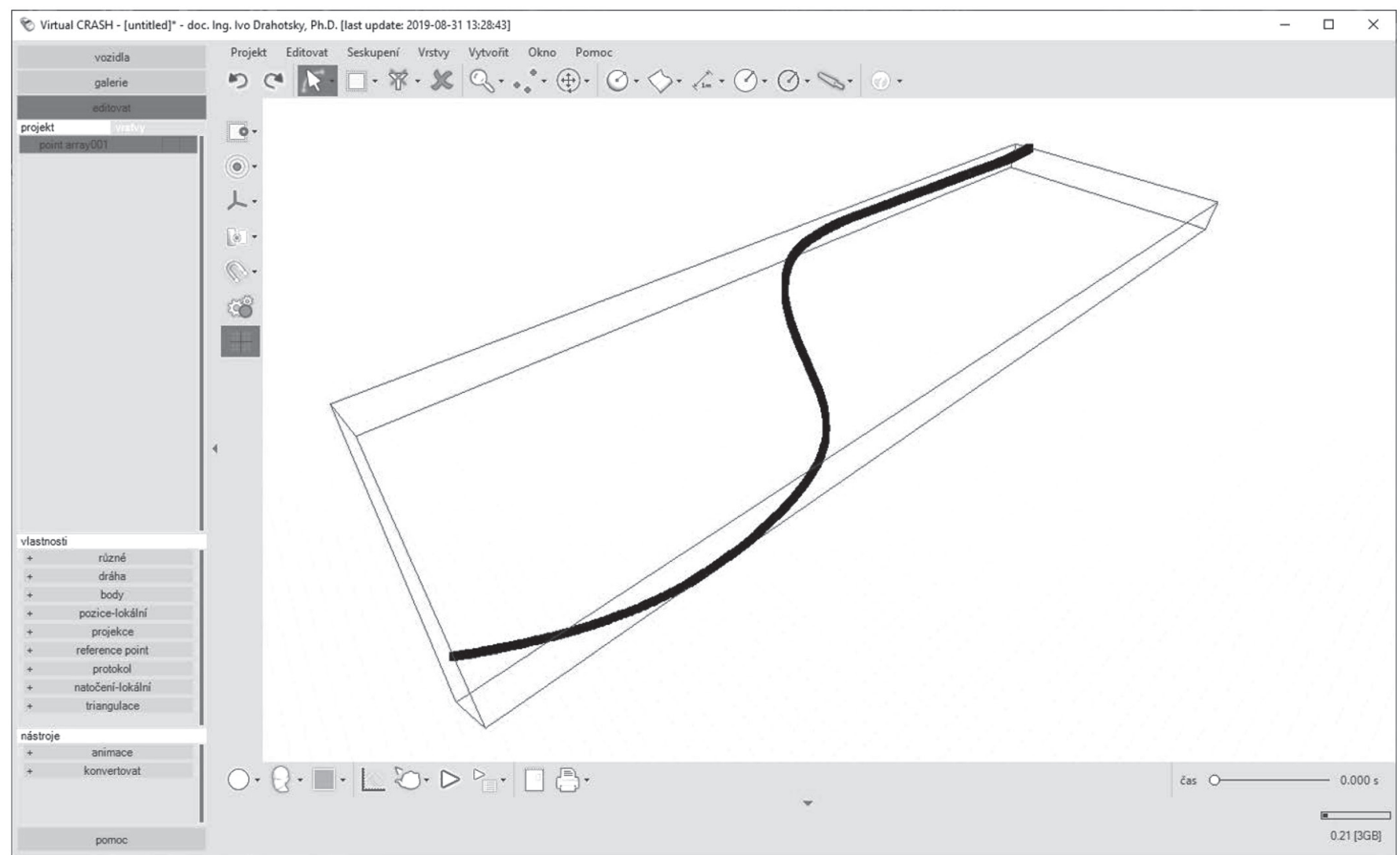

Obr. 10 Dílči kroky postupu tvorby linie komunikace (pokračování).

Fig. 10 Steps of road model proces (continuation).
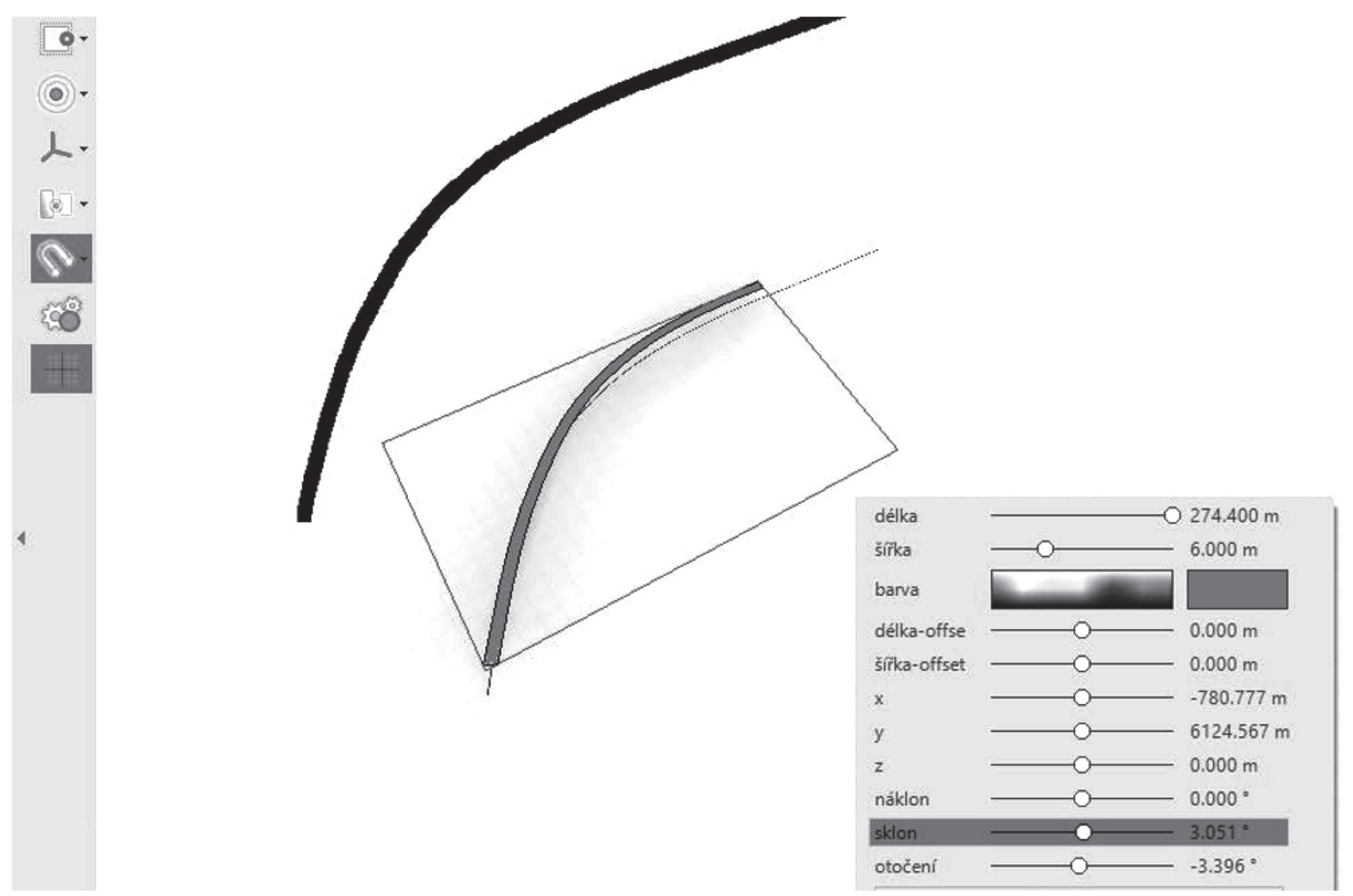

Obr. 11 Vyjádření sklonu komunikace.

Fig. 11 Road tilt. 


\section{Profil}

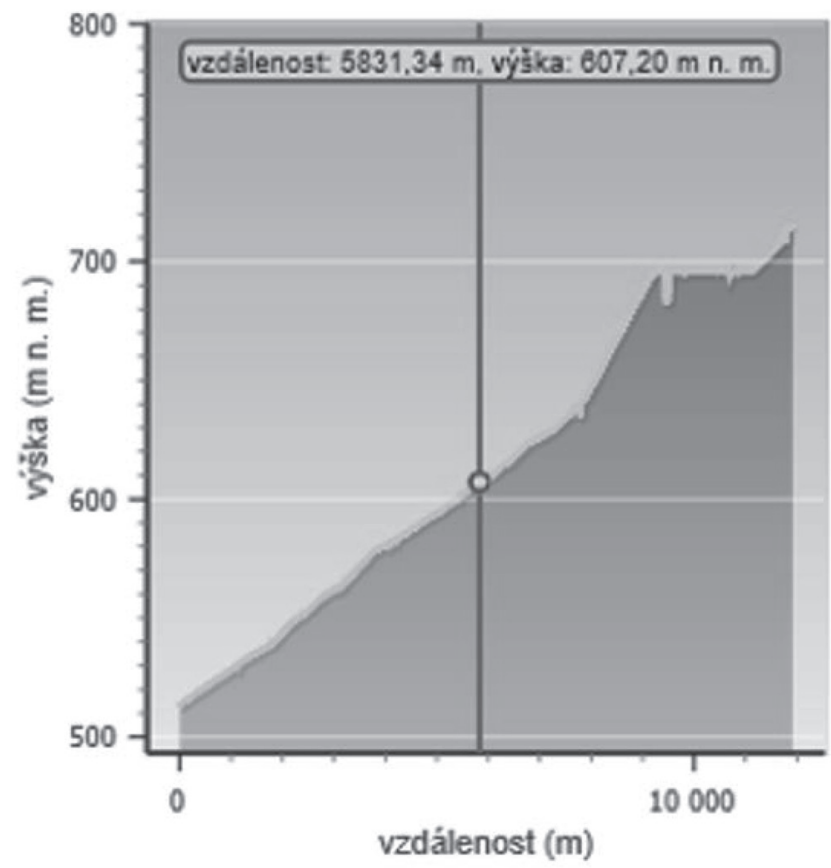

Obr. 11 Vyjádření sklonu komunikace (pokračováni). Fig. 11 Road tilt (continuation).

(s využitím přichycení $\mathrm{k}$ vrcholu). Tímto postupem získáme půdorysnou linii komunikace. Křivka je pouze v rovině $2 \mathrm{D}$; nelze ji naklopit (definovat sklon).

Z profilu komunikace však lze potřebné informace získat odečtením hodnot nadmořské výšky a sklon vyjádřit. Po vytvoření komunikace je tak možno využít vytvořenou křivku jako „dráhu“ („vybrat dráhu“), a sklon definovat zvlášt' u plochy, respektive komunikace (obr. 11).

\section{ZÁVĚR}

Předmětný příspěvek může obohatit poznání odborné veřejnosti využívající v rámci simulačních nástrojů $3 \mathrm{D}$ modelování terénu s aplikací veřejně dostupných geodetických dat. Popsaný postup lze samožrejmě různými způsoby modifikovat tak, aby byly plněny specifické požadavky, které v rámci analýzy silničních nehod vyvstávají.

\section{LITERATURA}

[1] https://www.cuzk.cz

[2] https://geoportal.cuzk.cz

[3] www.dsd.at

[4] www.vcrash.cz

[5] www.vcrashusa.com

[6] www.analzyanehod.cz

\section{Správná citace:}

DRAHOTSKÝ, I. Vytváření modelu terénu s využitím geodetických dat Českého úřadu geodetického a katastrálního v prostředí simulačních softwarů. Soudní inženýrství, 2020, 31(2), 2-13. DOI: http://dx.doi.org./10.13164/SI.2020.2.2. ISSN 1211-443X. 